\title{
Digital Transformation of the German State
}

\author{
Ines Mergel
}

'This project has received funding from the European Union's Horizon 2020 research and innovation programme under grant agreement No 770356. This publication reflects the views only of the author(s), and the Commission cannot be held responsible for any use, which may be made of the information contained therein.'

\section{INTRODUCTION}

The digital transformation of German public administration is an urgent matter, given that the public sector is generally lagging far behind the private sector and especially in comparison with digitalisation efforts across Europe. As one of the largest economies in the world, Germany has consistently been ranked in the low- to mid-field of digital government rankings (see, DESI 2019). In addition, recent polls have shown that the

I. Mergel $(\bowtie)$

University of Konstanz, Konstanz, Germany

e-mail: ines.mergel@uni-konstanz.de

(C) The Author(s) 2021

S. Kuhlmann et al. (eds.), Public Administration in Germany, Governance and Public Management, https://doi.org/10.1007/978-3-030-53697-8_19 
German public's use of existing digital services has been steadily declining during the past few years even though large-scale investments in IT spending have been made (Initiative 21 (2018/2019)).

These developments can be traced back to delays in supporting policy developments, lacking investments for necessary modernisation and the resulting backlog in IT capacity and failures to update IT legacy systems. The multilevel system of Germany's federal, state and municipal public administrations makes the decision and implementation approach even more complicated. Many activities with respect to IT governance and implementation are outsourced to external IT service providers, leaving public administrations devoid of the skills and competences necessary to innovate on their own and relying on external IT expertise for buying and implementing digital technology (Dunleavy et al. 2006).

Recently, the German government has embarked on a large-scale reform of its public service delivery mode-all 575 public services will be digitally transformed by 2022 - a reform in scale and scope that no other country has yet set out to approach (Mergel 2019). This reform plan demands certain coordination tasks across the federal system, which will be discussed in this chapter.

The goal of this chapter is to outline the recent development of digital transformation of public services in Germany, provide insights into the legal framework guiding the digital transformation efforts, its organisational embeddedness and multi-organisational collaborative governance approach, the barriers and challenges imposed by the multilevel institutional context of the German government and the observable outcomes to date.

\section{Current Status of Digital Transformation IN GERMANY}

Digital innovation in the public sector is slowly progressing in Germany. This is mostly due to the independence between administrative levels leading historically to relatively independent progress across administrative levels (see Chaps. 3 and 8). Most recently, Article 91c (1) of the Basic Law aimed to heal this disconnect by mandating that federal and state levels cooperate in the planning, establishment and operation of the information technology systems required to fulfil their tasks. Article 9lc (2) stipulates 
that the federal government and the Länder can define the standards and security requirements necessary for communication between their information technology systems. What remains undefined and open is how the 11,000 municipalities are going to adopt the standards set by the federal and state government administrations. Based on their self-administration right established in accordance with the provisions of Article 28 (2) of the Basic Law, municipalities remain independent in their decision making so that the use of top-down developed standards, platforms and security needs to be reviewed and additional funding needs to be made available (see Chap. 9).

Even though Article 9lc has initiated a functional reform at the federal and state government levels, digitalisation efforts still remain a sore topic in Germany. While the majority of German citizens are highly active on social media and shop online (ninety-three per cent), only five per cent are willing to use digital public services (InitiativeD21 2018/2019). This is a phenomenon that needs to be understood in light of the historical circumstances of Germany's political system. Especially since the Third Reich, Germans have been very reluctant to hand over data to the government in fear of becoming transparent citizens. The power distance felt between bureaucrats and citizens is increased by a general feeling that public administrations are slow, overly bureaucratic, and that access to public services is bogged down by excessive administrative burden.

It is only recently, from 2018 to 2019 , that the use of digital public services has slightly increased (InitiativeD21 2018/2019). However, many online public services and administrative apps are not used by citizens because they are inaccessible or require additional hardware to access services related to the eID and a personal service account. This is a continuous trend and comes with accessibility burdens that require a high degree of administrative literacy, which many citizens do not encounter in their otherwise personal online experiences on websites such as Amazon. de (Grönlund et al. 2007).

\subsection{Legal Framework for the Digital Transformation of the German State}

The legal framework governing digital transformation in Germany consists of a much larger web of laws that have developed over time. The 
foundation was laid with Article 9lc of the Basic Law which establishes that the federal government and the Länder may cooperate in the planning, construction and operation of the information technology systems required for the fulfilment of their tasks. This was further developed into an e-government law, which incorporates the access to electronic information, online payments through SEPA direct debit, electronic filing, publication of regulations online, open data, and the replacement of the written form by using a government email service (De-Mail) and web access through eID (electronic identification). However, many existing administrative laws are still preventing a fast and unbureaucratic transition from analogue to digital government. Examples include the paper form requirement, required (hand)written signatures on official administrative forms, or the personal and physical handing over of documents (instead of digital provision).

The implementation of digital government practices follows the cooperative approach outlined in Article 9lc of the Basic Law, but the administrative practice shows that coordination issues remain based on the federal approach towards negative coordination and the self-governing principle of the municipalities. Solutions are developed at the federal and state level, and it is only after the solutions have been consensually agreed upon that potentially negative consequences that might impact other stakeholders are reviewed. As a result, the Länder are aiming to coordinate their efforts among mid-level public managers at so-called expert conferences and are bringing the results of their negotiations to the IT Planning Council, which is a committee consisting of the state-level Chief Information Officers (CIOs), the federal government $\mathrm{CIO}$ as well as selected representatives of interest groups.

With the help of the IT treaty, the IT Planning Council is responsible for the planning, construction, operation and advancement of the information technology infrastructure. They set IT standards, such as safety requirements for data exchange, and coordinate the collaboration across the federal and state levels. In its amendment, this collaboration was recognised for its immense complexity due to the heterogeneity of the existing structures, processes and legal requirements. To solve this complex coordination problem, a new federal public institution for IT cooperation (FITKO) was created to support the IT Planning Council in all organisational issues and provides technical support starting January 2020. The 
main goal is to coordinate the multilevel coordination and to set up a joint digitalisation budget to support the digital transformation of public service delivery. This will allow the IT Planning Council to focus on its political coordination role among the Länder CIOs and leave technical details and implementation issues to FITKO.

Currently, most public services are, however, paper-based, still require a handwritten signature and need to be applied for in person. There are few instances where forms are already available online in pdf format. These forms are most of the time not connected to a database that would automatically transfer the data to the local authority. Instead, citizens print out the forms at home, walk them into the agency, watch a public servant type in the data and then provide a handwritten signature on a printed paper form. At times, it is possible to schedule appointments online or participate in information-based polls.

With the online access law (Online-Zugangsgesetz-OZG), the German government has set out to make analogue public services available by transforming them into a new citizen-centric service that will be available $24 / 7$. Service provision will be facilitated through one federal portal to which all sixteen state portals are connected. Each citizen will have his own eID and service account, so that services are accessible and data is exchangeable between agencies when necessary. Federal, state and local government levels are required to offer 575 public services online by 2022 .

The implementation is currently divided into two large-scale projects:

- Digitalisation programme: a total of 575 administrative processes and public services will be digitised. These services are located at various administrative levels. The services are divided into fourteen subject areas. One tandem, each from the federal ministry and the Länder, has taken the lead for a subject area. In these subject areas, public services are prepared for digitisation. After a detailed analysis, concrete digitisation plans are drawn up for each service. Particularly important services were prioritised within the thematic areas and are developed in so-called digital laboratories. Within these labs, interdisciplinary teams of experts from specialist departments, e-government experts and human-centred designers work in crossfunctional teams on user-centric solutions. 
- National portal network: the portal provides the technical linkages to the sixteen Länder administrative portals and their municipalities and ensures interoperability between the three administrative levels. This is intended to provide uniform access to all digital services offered by the administration. User accounts for citizens and companies are provided in the portal network for the authentication of users to access digital public services.

One important implementation challenge remains: the municipalities are not explicitly named in the law and it is up to the Länder to include them in their efforts. One way to consolidate the communication and coordination to the 11,000 municipalities is the inclusion of municipal interest organisations that bring in the interests of the municipalities. At this stage, it is unclear how the municipalities will be involved beyond the initial prototypes. Some Länder have developed their own portals and provide the digitised services to their municipalities free of charge, while others have not yet started to plan how to involve the municipalities in roll-outs or in the subsequent use of the functional prototypes already created.

Each new law is reviewed by a federal body, the National Regulatory Control Council (Nationaler Normenkontrollrat-NKR; see Chap. 20 for a detailed overview of the NKR). The NKR is located in the chancellor's office and serves in an advisory role. Laws are reviewed based on their potential to increase subsequent costs, evaluate their potential to lower bureaucratic burden and to simplify existing administrative processes. The online access law is explicitly designed to lower administrative burden and to increase access to public services to those who are willing to conduct them online. However, the NKR has repeatedly highlighted in its annual reports that the actual implementation is stalling, too complex, not sufficiently coordinated, and given the way in which implementation is organised, the OZG goals might not be achieved by the deadline.

In summary, the laws governing the digital transformation of the German state are listed in Table 19.1. 
Table 19.1 Overview of laws governing the digital transformation of the German state

\begin{tabular}{|c|c|c|c|}
\hline Name of the law & Date & Content & $\begin{array}{l}\text { Scope of } \\
\text { application }\end{array}$ \\
\hline $\begin{array}{l}\text { Act amending the } \\
\text { Basic Law } \\
\text { (Grundgesetz) } \\
\text { (Articles 91c, 91d, } \\
104 \mathrm{~b}, 109,109 \mathrm{a}, \\
115,143 \mathrm{~d} \text { ) }\end{array}$ & $\begin{array}{l}29 \text { July } \\
2009\end{array}$ & $\begin{array}{l}\text { Amendment of the Basic Law within } \\
\text { the framework of the Conference on } \\
\text { Federalism II with specific focus on } \\
\text { the cooperation between federal and } \\
\text { state government with respect to } \\
\text { standards and security measures }\end{array}$ & Federal, states \\
\hline $\begin{array}{l}\text { IT State Treaty on } \\
\text { the establishment } \\
\text { of the IT Planning } \\
\text { Council }\end{array}$ & $\begin{array}{l}1 \text { April } \\
2010\end{array}$ & $\begin{array}{l}\text { Establishment and regulation of the } \\
\text { working methods of the IT Planning } \\
\text { Council as a steering committee for } \\
\text { general IT cooperation }\end{array}$ & Federal, states \\
\hline $\begin{array}{l}\text { Law on the } \\
\text { promotion of } \\
\text { electronic } \\
\text { administration } \\
\text { (e-government } \\
\text { law) }\end{array}$ & $\begin{array}{l}25 \text { July } \\
2013\end{array}$ & $\begin{array}{l}\text { Enables the federal, state and local } \\
\text { governments to offer simpler, more } \\
\text { user-friendly and more efficient } \\
\text { electronic administrative services }\end{array}$ & $\begin{array}{l}\text { Federal, states, } \\
\text { municipal }\end{array}$ \\
\hline $\begin{array}{l}\text { Federal IT } \\
\text { consolidation as } \\
\text { part of the Digital } \\
\text { Agenda }\end{array}$ & $\begin{array}{l}20 \text { May } \\
2015\end{array}$ & $\begin{array}{l}\text { The aim is to vertically consolidate } \\
\text { the federal government's information } \\
\text { technology and to ensure economic } \\
\text { viability }\end{array}$ & $\begin{array}{l}\text { The federal } \\
\text { government } \\
\text { commissioner for } \\
\text { information } \\
\text { technology }\end{array}$ \\
\hline $\begin{array}{l}\text { Act for the } \\
\text { Improvement of } \\
\text { Online Access to } \\
\text { Public Services } \\
\text { (OZG) }\end{array}$ & $\begin{array}{l}14 \\
\text { August } \\
2017\end{array}$ & $\begin{array}{l}\text { By } 2022, \text { the federal government, } \\
\text { the Länder and the municipalities } \\
\text { should be able to offer all } \\
\text { administrative services in digital form }\end{array}$ & $\begin{array}{l}\text { Federal, states, } \\
\text { municipal }\end{array}$ \\
\hline $\begin{array}{l}\text { Coalition Treaty of } \\
\text { the } 19 \text { th legislative } \\
\text { period }\end{array}$ & $\begin{array}{l}7 \\
\text { February } \\
2018\end{array}$ & $\begin{array}{l}\text { Within the scope of the coalition } \\
\text { agreement, several e-government- } \\
\text { related projects were agreed upon }\end{array}$ & $\begin{array}{l}\text { Federal, states, } \\
\text { municipal }\end{array}$ \\
\hline $\begin{array}{l}\text { Law for the first IT } \\
\text { amendment treaty }\end{array}$ & $\begin{array}{l}6 \text { June } \\
2019\end{array}$ & $\begin{array}{l}\text { Advancing the development of IT } \\
\text { cooperation in public administrations } \\
\text { by FITKO }\end{array}$ & Federal, states \\
\hline
\end{tabular}

Source: Author's own compilation 


\section{Implementation Responsibilities of Digital Transformation in Germany}

The responsibilities for different aspects of IT governance are distributed not only horizontally across different federal ministries, but also vertically throughout the multilevel system across federal, state and municipal government levels.

\subsection{Horizontal Distribution of Responsibilities Across Federal Ministries}

At the federal level, the responsibilities are located in at least five different federal ministries or departments.

The Ministry of Transport and Digital Infrastructure (BMVI.de) is responsible for the improvement of the Long Term Evolution (LTE) and fibre-optic broadband deployment, the promotion of digital innovation technologies in the mobility sector as well as automated and networked driving. It also develops the Federal Government's Artificial Intelligence Strategy, which was drawn up under the joint leadership of the Federal Ministry of Education and Research, the Federal Ministry of Economics and Energy and the Federal Ministry of Labour and Social Affairs. Its goal is to establish Germany and Europe as a leading AI location and thus contribute to securing Germany's future competitiveness. The aim is to develop and use AI responsibly and in the public interest. AI will also be used to automate public service delivery or proactively deliver services to citizens.

The Federal Ministry of Economic Affairs and Energy (BMWI.de) is in charge of creating a legally secure future framework for digital change and a modern net policy. The design of the digital economy (e.g., Sharing Economy) includes a strategy for artificial intelligence and blockchain. The goal is to create an intelligent interconnectedness between the education, energy, health, and transport sectors.

The Federal Ministry of the Interior, Building and Community (BMI. de) is responsible for the implementation of the Act for the Improvement of Online Access to Public Services (OZG) and the coordination of the Open Government initiative. It houses the data ethics commission and the agency for innovation in cyber security. As part of the implementation of the OZG, the BMI is establishing the national portal and the portal network as a technical prerequisite for digitalisation of public services. The 
work is being carried out in so-called digitisation laboratories and focusses on the different life cycles of citizens. It involves steps, such as the register modernisation and also the IT consolidation at the federal level. It has served as the initiator within the framework of federal cooperation including the FITKO and IT Planning Council committees. The BMI has increased its responsibilities within the framework of e-government projects in the execution, coordination and control of the various measures initiated. Once completed, the services provided by the BMI will be accessible to all citizens of the state. BMI is also home to the recently established project team for the conception and development of a digital innovation team and e-government agency (DIT.BUND). DIT is using human-centric design and agile approaches and serves as a think-and-do tank for the federal government.

The German Chancellory has recently established its own digital service team-Digital Service 4 Germany, which evolved out of the private sector initaitive Tech4Germany and Work4Germany, a fellowship program that places technology experts in federal ministries to collabroatively work on IT projects. The digital service team is an initiative under the patronage of head of the Federal Chancellery and is considered a technology taskforce, comparable to the UK's Government Digital Service or the US' Digital Service. In addition, the federal CIO has initiated a cross-agency workgroup, NExT Netzwerk-a network that focuses on connecting federal government employees to develop and implement technology practices and competencies. The Federal Administration Office (BVA) is a federal agency in the portfolio of the Federal Ministry of the Interior, Building and Community. It performs a large number of federal administrative tasks and is active for some federal ministries and their business areas (for more details, see Chap. 5). The tasks include recovery of student loans, salaries and allowances of federal employees as well as citizenship matters. It also performs a variety of central services for other federal authorities, such as the payment of emoluments and allowances, travel expense management, time recording and personnel recruitment. The BVA has established its own organisational consultancy for other ministries and authorities and has already digitised a large number of tasks and processes. The BVA currently has around 120 digitisation and IT processes in use or under development. As the central service authority with many specialist tasks and customers, the BVA has developed a Digital Agenda, 'BVA.digital 2022', where all digital measures of the BVA are bundled and controlled. It specifically focusses on the development of the 
digital skills and competences of federal government employees. In addition, its agenda consists of four application areas:

1. Beihilfe App/Aid app: this is an app which allows eligible persons to quickly and easily apply for the reimbursement of eligible costs.

2. BVA.digital: in addition, eleven different digitisation principles have been developed, which serve as guidelines for the digitisation of tasks, business processes and offers.

3. Digital consulting: Federal Administration Office consultants support authorities in mastering this challenge and exploiting the potential of digitisation in a targeted manner.

\subsection{Vertical Distribution of Responsibilities Across Administrative Levels}

With respect to the current implementation of the online access law, the federal government is responsible for setting up the federal portal by 2022 and ensuring interoperability with state-level portals. The result will be a network of portals (Portalverbund) that electronically offers all public services taking accessibility criteria into consideration. The federal government is also responsible for creating user accounts and identification under the negotiated security standards. They are responsible for the federal IT consolidation. The aim of this consolidation of information technology is to ensure information security against the background of increasing complexity, be able to react to innovations and ensure an efficient, economical, stable and sustainable operation. Three strands of action lay the groundwork: (1) consolidation of operations, (2) consolidation of services and (3) procurement bundling.

The Länder are responsible for providing their electronic services on their own state portal and connecting them to the federal portal. The services are connected to the agencies responsible for delivering them. The challenge at the state level is that some states started this process long before the online access law was established. They have already invested in their own portal network, created partnerships with other states, selected their service providers and set their own standards. This contradicts in many ways the standards set by the law and the agreed-upon shared IT components, and new interfaces will likely need to be designed to be able to allow for nationwide interoperability-and in the future Europeanwide interoperability. 
The municipalities and their possible distribution of tasks are not explicitly mentioned in the law. The website of the IT Planning Council states: 'The municipalities are to be involved by the Länder'. However, only a handful of selected municipalities are involved in the digital labs to develop service prototypes and are, therefore, at the forefront of designing digital services in one specific life phase. The majority of municipalities are not involved and are dependent on the innovativeness and coordination ability of their respective states. Some states take this task very seriously and have distributed the tasks of public service design to the municipalities, while others have not yet had early discussions with their municipalities.

\section{Recent Developments: Citizen-Centric Digital Service Design}

E-government and digital transformation have become one of the core elements of the recently elected nineteenth coalition government. The coalition agreement includes the expansion of a high-speed network and the creation of a digital portal for citizens and businesses to provide easy, secure and mobile access to all administrative services. An additional $€ 500$ million will be available for the implementation of the online access law to improve online access to administrative services. The coalition has agreed to establish an e-government agency that will jointly develop standards and pilot solutions for all federal levels more quickly than before. For that purpose, one of the hallmarks of the German public service will be reviewed: the (hand)written form requirements. According to the coalition agreement, the federal government intends to strengthen the role of the federal government's IT commissioner.

A digital council consisting of German-speaking high-profile international academics and practitioners was established to advise the chancellor's office and bring in new ideas to move the digital transformation of the German public sector forward. The honorary council has met a few times, but no public announcements were made that provide insights into the guidance that the chancellor's office receives from the council. The goal for establishing the council is to receive critical external insights on the progress the German government is making with respect to digital transformation.

Some progress has been made by establishing e-filing across all levels of government. The most prominent example is the tax e-filing system. 
Using plain language, e-filing through the electronic filing system for tax returns, Elektronische Stenererklärung (ELSTER), has been available since 2019. With My Elster (formerly ElsterOnline-Portal), the tax administration has made a portal available through which citizens can register their own account, use their electronic filing ID to submit their tax declaration forms or request tax returns and so on.

New practices of citizen-centric public service design have initially been tried out in small pockets of the overall administrative system, originating mostly from the municipal government level. Networks such as the ANDI group (agile network for digital innovation) have started working with designers to bring innovative methods, such as a design thinking or human-centred design, to their digital transformation work (see, e.g., Ansell and Torfing 2014; Bason 2016; Junginger 2016). These bottomup efforts have subsequently spread to the federal level and are now officially established as part of the federal digital transformation efforts. Especially in the digital labs used to derive the requirement of digital public services, interdisciplinary teams of experts from across public administration collaborate with content experts to design user-centred public services. This new form of co-production is used to design services, not from the internal logic of government but from the perspective of those who need to use digital services in the future. These users can either be internal users (public servants) or external users, such as citizens and other stakeholders. The goal is to deliver services that are easier to use, have a higher success and acceptance rate and generally make the design process more democratic in nature.

What has not been addressed in either the laws or public discussions on digital transformation in Germany is the necessary build-up of digital competences in the public sector. While Germany has signed off on the European Digital Competency 2.0 framework (EU Science Hub n.d.), it has not yet started to come up with any form of comprehensive framework on how to build digital competences in order to prepare the public sector workforce for future challenges. There are initial plans to build a government digital academy serving all three levels of government and an eGovernment MOOC to bring digital competencies to civil servants. Results from expert interviews show that public managers need to be trained in developing a digital mindset. They need to understand what the role of new technologies is and build up digital fluency to switch between different types of technologies. Middle managers responsible for the implementation of digital transformation need to learn how to use new project management techniques to guide the implementation process. Public 
servants, and especially frontline workers, need to be able to participate in the digital transformation efforts, understand how efficiency gains are created, encourage citizens to use the tools and reduce administrative burdens during actual usage. This will help public servants to focus on more complex issues that need to be tackled in person and leave other tasks to those willing to conduct them online or use automated public service delivery. Another important stakeholder group includes the IT service providers and consultants who need to understand public service values as an achievement of the rule of law, instead of promoting the abandonment of federalism. Surprisingly, the experts uniformly highlight that citizens' digital competences are far more formed than those of public servants and do not necessarily need to be improved. Instead, public administrations need to simplify the design of public service delivery so that no additional skills need to be developed in the future and administrative burdens are reduced.

\subsection{Digital Transformation of Citizen Offices}

One recent advancement can be observed in the digitalisation of local one-stop shops. These are local government initiatives to advance e-government service provision bundled on one website, so that those digitally literate citizens have an opportunity to access information about the agency and its services 24/7.

According to Schwab et al. (2019), the focus is on two advancements. One can be described as the interactive process through which appointments are made with the agency, for example, to register a car or apply for a driver's licence. The other is accessing information about services offered online, including information about office hours or the general process, and to provide some of the necessary administrative forms online. These two services can be mostly observed in cities with more than 100,000 citizens.

Among the top cities in this area is Freiburg in Baden-Württemberg (see Digital.Freiburg.de) that uses idea labs to integrate citizen needs into the deliberate design of online public services. Other cities, for example the city-state Hamburg, are providing interactive options such as the chatbot 'Frag-den-Michel'. The chatbot is AI-supported and provides help to find services, locations and office hours.

However, face-to-face interactions between civil servants and citizens are still the norm. While citizens can prepare for some of these interactions 
using the documents and forms available online, citizen interactions are of a complex nature and need to be dealt with in an analogue discursive manner, potentially including several different agencies and not just through one frontline worker.

\subsection{Digital Transformation of the Federal Agency for Migration and Refugees}

Another prominent success story of a digitalised agency is the Federal Agency for Migration and Refugees (BAMF). Since the migration crisis of 2015 , the BAMF has increased the number of clients it serves on a regular basis from 40,000 refugees per year to around 800,000-1,000,000 refugees per year. This massive increase in scale needed to be reflected in the internal processes and distribution of responsibilities in order to effectively coordinate and trace refugees across all levels of government (Bogumil et al. 2018). The BAMF has set up an internal IT Lab that introduces new project management tools, such as Scrum to develop software together with the process owner, product owners and users. Scrum is an iterative project management practice that introduces the development of small project steps in so-called sprints. The project team is allowed to revisit previous project steps and adjusts the directions and requirements as they go along. The result is a minimal viable product that can be used to prototype the expected final product, and additional adjustments can be made when users are invited to test the prototype. The goal is to develop tools faster with fewer errors that are immediately usable for the users. The process is more democratic in nature than the standard waterfall technique that has led to large-scale IT failures in the past. The IT lab is a rather unique organisational setup, comparable to digital service teams in the UK or the US or innovation labs in Denmark. It is located in rooms with graffiti and artwork that are not usually found in a German bureaucracy, has large windows for transparency and demonstration purposes. As part of their mission, the agency's inhouse IT lab staff also provides administrative assistance to other agencies with responsibilities related to the immigration service, such as customs, border and local police, to share their knowledge and practices.

As a starting point, BAMF has used the refugee crisis to rethink its own IT management. It has developed a series of new tools in a relatively short amount of time that help to automate tasks related to refugee processing and handle the coordination efforts with other agencies, such as the 
municipal and state immigration office, first admissions by the states, federal agency for employment, police, customs, federal intelligence services and others. For this purpose, tools such as the migration tracker were created according to the Dublin procedure. For each refugee case, the procedure reviews which European country is responsible for accepting the refugee. The tool is used to coordinate arrivals at the initial reception facilities, register arrivals and provide proof of arrival. All immigration offices are now connected to the migration tracker and the data can be transferred to the police and especially to the courts. All documents are scanned, electronically distributed, and are made available to the connected agencies through the MARIS system, a workflow and document management system to process all asylum-related procedures. According to those responsible for the digitalisation of the BAMF processes, the digitalisation efforts themselves were not necessarily difficult. It was much more difficult to train public servants in applying new project management practices and work on cross-functional teams together with designers and software developers and help them move towards a digital mindset to establish and accept these new practices.

The BAMF is also the initiator of the NExT network which was founded in 2018 in collaboration with the federal chief information officer (CIO) (see https://www.next-netz.de/ for more information). NExT is an interdepartmental network of digital pioneers. These are experts in different federal ministries whose common goal is to significantly shape and advance the digital transformation of German public administration. The network is divided into six working groups that focus on: how digital projects can be developed; how digital skills can be increased; what new technologies public servants need to pay attention to; how organisational practices need to be adapted; what kind of cooperation is necessary and how the results can be communicated and distributed to public sector actors. This interorganisational network has the opportunity to distribute insights from different angles of the administrative system and share insights without reinventing the wheel over and over again.

\section{Lessons Learned and Practical Implications}

The developments and insights gained from the digital transformation experiences in Germany lend themselves to other countries-with similarly advanced bureaucracies and IT legacy systems that have been built up over many years. In countries with a comparable institutional context, 
where authority for policymaking and implementation is delegated to different types of actors across levels of government and jurisdictions, Germany may be a model to emulate and adapt to other local contexts. The all-encompassing reform that tackles publicly facing administrative service is a holistic approach to get up to speed in contexts in which policy and implementation of digital services have been slow to develop.

Those who are aiming to introduce a similar approach, however, can learn from the coordination mechanisms used by Germany. The focus on co-creation together with actors at all levels of government and with external stakeholders is unique in that it includes not only all levels of government but also citizens and related interest groups. However, the administrative practice shows that there is currently an over-reliance on external consultants and government-owned IT service providers. As soon as they pull out, contracts expire or projects end, there is a need to find another approach to sustain the development and implementation of digital services. The German government will need to focus on continuous service provision and scaling up to the 11,000 municipalities where most citizens access public services.

Digital transformation of the public sector is at its core a cultural change process that needs to be carefully guided with the input of public managers and cannot be driven bottom-up by frontline workers (Mergel et al. 2019). Public servants need to be included each step of the way to provide their feedback, experience the potential changes coming their way as well as guide the transformation with their technical input.

\section{Notes}

1. https://www.govdata.de.

2. https://www.bundeshaushalt.de.

\section{REFERENCES}

Ansell, C., \& Torfing, J. (Eds.). (2014). Public Innovation Through Collaboration and Design. Abingdon: Routledge.

Bason, C. (2016). Design for Policy. New York, NY: Routledge.

Bogumil, J., Burgi, M., Kuhlmann, S., Hafner, J., Heuberger, M., \& Krönke, C. (2018). Bessere Verwaltung in der Migrations- und Integrationspolitik: Handlungsempfehlungen für Verwaltungen und Gesetzgebung im föderalen System. Baden-Baden: Nomos. 
DESI. (2019). The Digital Economy and Society Index (DESI) Ranking. Retrieved November 2, 2019, from. https://ec.europa.eu/digital-single-market/desi.

Dunleavy, P., Margetts, H., Bastow, S., \& Tinkler, J. (2006). New Public Management Is Dead-Long Live Digital-Era Governance. Journal of Public Administration Research and Theory, 16(3), 467-494.

EU Science Hub. (n.d.). The Digital Competence Framework 2.0. Retrieved from https://ec.europa.eu/jrc/en/digcomp/digital-competence-framework.

Grönlund, Å., Hatakka, M., \& Ask, A. (2007). Inclusion in the E-Service SocietyInvestigating Administrative Literacy Requirements for Using E-Services. In International Conference on Electronic Government (pp. 216-227). Berlin, Heidelberg: Springer.

Initiative 21. (2018/2019). Egovernment Monitor 2018/2019.

Junginger, S. (2016). Transforming Public Services by Design: Re-Orienting Policies, Organizations and Services Around People. New York, NY: Routledge.

Mergel, I. (2019). Digitale Transformation als Reformvorhaben der deutschen öffentlichen Verwaltung. dms—der moderne staat-Zeitschrift für Public Policy, Recht und Management, 12(1), 162-171.

Mergel, I., Edelmann, N., \& Haug, N. (2019). Defining Digital Transformation: Results from Expert Interviews. Government Information Quarterly, 1-16. https://doi.org/10.1016/j.giq.2019.06.002.

Schwab, C., Bogumil, J., Kuhlmann, S., \& Gerber, S. (2019). Digitalisierung von Verwaltungsleistungen in Bürgerämtern. In T. Klenk et al. (Eds.), Handbuch Digitalisierung in Staat und Verwaltung. Wiesbaden: Springer. 



\title{
Appendix: Open Government
}

\author{
Jan Porth, Friederike Bickmann, Patrick Schweizer, \\ and Zarina Feller
}

\begin{abstract}
App. 1. Introduction
When considering political and administrative actions over the past decades, a general trend towards more openness can be observed (Meijer et al. 2014: 103-104). Internet portals, where large quantities of administrative data are available to be used freely by the general public, are examples of this trend, which is generally supported by technological advances (von Lucke 2017: 155ff.). Alongside the different motivations for these changes, different terms are used to describe this development. However, the term open government is becoming increasingly common-also in Germany-to refer to actions generally increasing the openness of the political-administrative system.

According to the Organisation for Economic Co-operation and Development (OECD), open government can be defined as 'a culture of governance based on innovative and sustainable public policies and practices inspired by the principals of transparency, accountability and participation that fosters democracy and inclusive growth' (OECD 2016: 3-4).
\end{abstract}

J. Porth $(\bowtie) \bullet$ F. Bickmann $\bullet$ P. Schweizer $\bullet$ Z. Feller German Research Institute for Public Administration, Speyer, Germany e-mail: porth@foev-speyer.de; bickmann@foev-speyer.de; schweizer@foev-speyer.de; feller@foev-speyer.de 
The principles of transparency and participation are also part of Barack Obama's Open Government Directive of 2009. Instead of accountability, he included collaboration as the third element of open government (Executive Office of the President 2009: 1). Going back to the differences in the conceptual understanding of open government, the term is used in the context of a wide variety of policy measures in practice.

The possible advantages of open government are closely related to its principles. Civil society, the economy as well as the administration itself can benefit from increased openness of policy decisions and administrative actions, which may also strengthen the relationships between these actors. In addition, the involvement of citizens and their ideas can help to make administrative processes more citizen-friendly. Disadvantages, on the other hand, may arise in terms of extensions of policy and planning processes due to the involvement of more external actors as well as the possible demotivation of participants whose ideas or proposals cannot always be taken into consideration.

Criticism of open government further points out a possible lack of democratic legitimacy (Wewer and Wewer 2019: 11). While the understanding of the types of measures which are part of open government differs, the problems of legitimacy are not apparent for most types of initiatives. This also applies, for example, to the advisory roles of external actors in political-administrative processes, which have a long tradition in many countries and do not replace the decisions taken by elected representatives.

The Open Government Partnership was founded in 2011 as an international initiative to promote open government. So far, more than seventy countries are part of the initiative. Germany joined the partnership in 2016. The member states are obliged to develop national action plans in cooperation with civil society. The action plans comprise specific commitments in areas such as open data and citizen participation (Federal Chancellery 2019; Federal Ministry of the Interior 2017).

Germany's current national action plan for the years 2019-2021, for example, includes commitments to the establishment of an e-government agency as a digital innovation team of the federal administration, the further development and promotion of the open data environment and better regulation through participation and testing. The nine commitments by the federal government are complemented by further commitments by some state governments (Federal Chancellery 2019). 
While initiatives in the context of open government can be found in various policy areas and at different levels of government, the following sections will focus on three sub-fields, namely open government data (Sect. App. 2), open innovation (Sect. App. 3) and open budget (Sect. App. 4), where a comparatively large number of activities has been identified. Each section addresses the current state of affairs at the federal level in Germany from a legal and practical perspective. The insights gained and existing potentials for further open government activities are then summarised (Sect. App. 4).

\section{App. 2. Open Government Data}

Open government data is one of the most well-known sub-fields of open government focussing on the free availability of administrative data for further use (Ubaldi 2013: 6). While the publication of administrative data enhances transparency, private companies and administration itself can also benefit from the exchange and further use of data. For some types of governmental data, such as geographical data, the provision implies considerable business opportunities for the private sector.

Since 2017, section 12a of the E-government Act (EGovG) obliges direct federal authorities to provide unprocessed data, which they collect or receive in the context of the fulfilment of their tasks, via public networks. Furthermore, Germany is legally bound by the European Directive 2013/37/EU amending Directive 2003/98/EC on the re-use of public sector information (the PSI Directive) obliging the member states to make public sector information accessible and reusable. In Germany, the directive was transposed into national law through the First Amendment of the Re-Use of Information Act (IWG). In 2019 the European Directive (EU) $2019 / 1024$ on open data and the re-use of public sector information passed which encourages member states of the EU to extend the provision of government data for further usage, especially for economic purposes. The member states shall implement the directive into national law until July 2021.

Based on an administrative arrangement of 2014 between the federal government and several federal states, the data portal GovData ${ }^{1}$ was established in order to collectively provide data from various public authorities on the Internet. Two types of data licences, one requiring source specifications and one without any restrictions or conditions, were developed to enable the legal reuse of the data. The decision on the licence used is taken by the provider of a dataset. Today, a wide range of data relating to various 
policy areas is available on the platform. In addition, open government data are available on other platforms operated by federal, state and municipal governments.

\section{App. 3. Open Innovation}

According to Henry W. Chesbrough, the economist who coined the term, 'Open Innovation means that valuable ideas can come from inside or outside the company and can go to market from inside or outside the company as well' (Chesbrough 2003: 43). By enabling inclusion of the ideas of external actors, opening up the innovation processes can generate a number of advantages, for example optimised workflows, for any type of organisation. Public authorities can also benefit from this approach.

In the context of open government, open innovation is also a possible tool for strengthening the connection between administration and the general public. Government officials can add to their knowledge, especially about citizens' needs, by allowing input from outside the public sector. Citizens, on the other hand, can participate more directly in public matters and increase their influence on governmental decision-making.

In Germany, section 19 of the Regulation on the Award of Public Contracts $(\mathrm{VgV})$ further allows public authorities to establish innovation partnerships with private companies with the intention of creating innovative products or services, which are not yet available on the market. However, the use of this procurement procedure has remained limited so far. Also, the civil dialogue 'Wellbeing in Germany', which was conducted between 2015 and 2016 and included discussions between federal politicians and citizens about the living conditions and quality of life in Germany (Federal Government 2020), can be considered as an activity in the context of open innovation.

\section{App. 4. Open Budget}

Open budget refers to the opening of the budget as well as the budgetary cycle of public authorities with the objective of providing information and enabling the free reuse of budgetary data. In some cases, a consultative participation of citizens and private businesses in budgetary affairs is also intended. Comparable to many other areas of open government activities, open budget fosters transparency and participation in particular. Open budget data and open contracting can be considered as sub-areas of open 
budget. While the former focusses on budget data for analytical and research purposes, the latter addresses the disclosure of public authority contracts with all their contractual clauses.

In Germany, the disclosure of the budgets is required by law. According to Article 110 of the Basic Law, all federal revenues and expenditures need to be included in a budget plan, which can be part of the draft of a budget law. The draft law needs to be approved by the Bundestag, while the Bundesrat can deliver its opinion. On the grounds that the Bundestag generally debates publicly (Article 42 of the Basic Law), the federal budget is publicly available. Further provisions covering the federal budget are regulated by the Federal Budget Code (BHO).

In addition to the publication as part of the federal budget law, the federal budget is interactively and freely accessible on a website ${ }^{2}$ operated by the Federal Ministry of Finance. The website enables a detailed exploration of the budget, including graphical illustrations of the allocations of the individual budget items, year-on-year comparisons and a keyword search.

\section{App. 5. Lessons Learned}

The German government and public authorities have become more open in recent years. Changes in political convictions and priorities coupled with the commitments in the context of the participation in the Open Government Partnership have led to a broad range of initiatives generally aiming to improve transparency, accountability and participation.

However, for some types of information and data, such as legislative texts and budget plans, it is important to note that public availability has existed in Germany for many decades, even centuries. The changes in the context of open government mainly affect the types and convenience of availability. While, for example, access to printed legal gazettes and exploring content requires substantial efforts, the full-text search of legal documents readily available on the Internet can be considered as a significant relief and, therefore, progress in terms of openness.

Although the German federal government has implemented various open government initiatives, the user groups and utilisation processes of the initiatives have not been fully evaluated yet. Further efforts could focus on gaining a better understanding of the user side of open government. If necessary, measures could be taken to reach broader groups of users, for example by developing more tailored offers and more widely 
promoting existing activities. New measures to promote open government by emphasising its potentials could also be addressed to the administration itself. Additional steps to improve and further develop current open government initiatives, for example by expanding data visualisations and search options, could also be considered.

Further attention should also be given to the interrelations between the various initiatives as well as the sub-fields of open government. The measures related to open innovation, for example, can largely benefit from open government data. A focus on interrelations could also support the development of a more uniform understanding of open government in general.

Besides the federal government, the state governments and many local governments have also implemented measures in the area of open government in Germany in recent years. Some larger cities, for example, operate their own open data and/or open budget portals. Furthermore, the project 'model municipality open government' by the Federal Ministry of the Interior, Building and Community and the municipal umbrella organisations have supported open government initiatives in selected municipalities with the general aim of promoting open government at the sub-national level (Federal Ministry of the Interior, Building and Community 2019). Stimulating increased collaboration and the exchange of ideas between public authorities across all levels of government could be a promising approach to further exploit the potential of open government in Germany.

\section{App. 6. References}

Chesbrough, H. W. (2003). Open Innovation. The New Imperative for Creating and Profiting from Technology. Boston: Harvard Business School Press.

Executive Office of the President. (2009). Open Government Directive. Retrieved February 3, 2020, from https://obamawhitehouse.archives.gov/sites/default/ files/omb/assets/memoranda_2010/ml0-06.pdf.

Federal Chancellery. (2019). Second National Action Plan (NAP) 2019-2021 in the FrameworkofGermany's Participation in the Open GovernmentPartnership (OGP). Retrieved February 9, 2020, from https://www.opengovpartnership.org/ wp-content/uploads/2019/09/Germany_Action-Plan_2019-2021_EN.pdf.

Federal Government. (2020). Wellbeing in Germany. Retrieved February 11, 2020, from http://www.gut-leben-in-deutschland.de/static/LB/en/.

Federal Ministry of the Interior. (2017). First National Action Plan (NAP) 2017-2019 in the Framework of Germany's Participation in the Open Government Partnership (OGP). Retrieved February 9, 2020, from https:// 
www.opengovpartnership.org/wp-content/uploads/2017/08/Germany_ NAP_2017-2019_ENG-transl.pdf.

Federal Ministry of the Interior, Building and Community. (2019). Modellkommune

Open Government, Projektbericht. Retrieved February 9, 2020, from https:// www.bmi.bund.de/SharedDocs/downloads/DE/veroeffentlichungen/themen/moderne-verwaltung/projektbericht-modellkommune-open-government.pdf?_blob=publicationFile\&v $=2$.

von Lucke, J. (2017). Technische Innovation-Potenziale von Open Government,

Offenen Daten und Intelligenten Städten. In N. Kersting (Ed.), Urbane Innovation (pp. 151-204). Wiesbaden: Springer.

Meijer, A., de Hoog, J., van Twist, M., van der Steen, M., \& Scherpenisse, J. (2014). Understanding the Dynamics of Open Data: From Sweeping Statements to Complex Contextual Interactions. In M. Gascó-Hernández (Ed.), Open Government. Opportunities and Challenges for Public Governance, Public Administration and Information Technology (vol. 4, pp. 101-114). New York: Springer.

OECD. (2016). Open Government: The Global Context and the Way Forward. Paris: OECD Publishing.

Ubaldi, B. (2013). Open Government Data: Towards Empirical Analysis of Open Government Data Initiatives. OECD Working Papers on Public Governance No. 22. Retrieved February 6, 2020, from https://www.oecd-ilibrary.org/ docserver/5k46bj4f03s7-en.pdf.

Wewer, G., \& Wewer, T. (2019). Open Government, Stärkung oder Schwächung der Demokratie? Wiesbaden: Springer VS.

Open Access This chapter is licensed under the terms of the Creative Commons Attribution 4.0 International License (http://creativecommons.org/licenses/ by $/ 4.0 /$ ), which permits use, sharing, adaptation, distribution and reproduction in any medium or format, as long as you give appropriate credit to the original author(s) and the source, provide a link to the Creative Commons licence and indicate if changes were made.

The images or other third party material in this chapter are included in the chapter's Creative Commons licence, unless indicated otherwise in a credit line to the material. If material is not included in the chapter's Creative Commons licence and your intended use is not permitted by statutory regulation or exceeds the permitted use, you will need to obtain permission directly from the copyright holder.

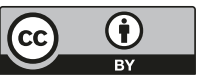

